\section{AMOR E ALUSÃO À MORTE: UM ESTUDO ACERCA DAS REPRESENTAÇÕES DAS HEROÍNAS DE OVIIDIO}

\begin{abstract}
RESUMO: As heroínas construídas por Ovídio, na obra Epistulae Heroidum, vivenciam amores extremos, que as levam a pensar na morte como escapatória dos sofrimentos que enfrentam na ausência de seus seres amados. Muitas das personagens representadas por Ovídio prometem cometer suicídio se não conseguirem trazer de volta os heróis ausentes. Neste artigo, objetivamos analisar como o amor e a morte são partes integrantes do pensamento ovidiano expresso nas Heroides.
\end{abstract}

PALAVRAS-CHAVE: Ovídio; Heroínas; Morte; Amor; Suicídio.

\section{LOVE AND THE ALLUSION TO DEATH: A STUDY ABOUT THE REPRESENTATIONS OF OVID'S HEROINES}

ABSTRACT: The heroines built by Ovid, in his work Epistulae Heroidum, experience extreme loves, which lead them to think of death as an escape from the sufferings they face in the absence of their loved ones. Many of the characters represented by Ovid promise to commit suicide if they can not bring back the missing heroes. In this article, we aimed to analyze how love and death are part of the thought expressed in the Ovidian Heroides parties.

KEYWORDS: Ovid; Heroines; Death; Love; Suicide.

Amor e morte, na Antiguidade Romana, estavam intimamente relacionados. Percebemos, na documentação literária analisada, que tal relação poderia ser construída através da menção à morte em decorrência dos sofrimentos ocasionados pelo amor tido como desmedido, pela morte do homem

\author{
* Professora Associada \\ II de História Antiga e \\ Medieval da Universidade \\ Federal de Goiás\Brasil. \\ Doutora em História \\ pela USP. Coordenadora \\ do LEIR-GO. Bolsista. \\ Produtividade II do CNPq. \\ anateresamarquesgoncalves@ \\ gmail.com. Produtividade \\ II do CNPq. \\ anateresamarquesgoncalves@ \\ gmail.com \\ ** Mestranda no Programa \\ de Pós-Graduação em \\ História da Universidade \\ Federal de Goiás। \\ Brasil, sob orientação da \\ Profa. Dra. Ana Teresa \\ Marques Gonçalves. \\ Bolsista do CNPq. \\ marianacarrijomedeiros@ \\ gmail.com
}


que, muitas vezes, requer também a morte de uma mulher, e ainda pelo amor que venceu a morte ou até mesmo a menção à morte como um aparato retórico. Tendo em vista tais apontamentos, no presente artigo, tomamos por base o documento Epistulae Heroidum, do poeta latino Públio Ovídio Nasão (I a.C./I d.C.). Nossa investigação se centra na análise das heroínas construídas por tal poeta nesta obra, as quais realizam menção ao suicídio ou ao simples desejo de morrer por não mais suportarem a ausência do amado herói, bem como devido aos desvarios ocasionados pelas desmedidas do amor irracional. Pensamos aqui a morte como um ato último e desencadeado pelo amor desmedido e desarmônico. Cabe-nos indagar, portanto, se tal menção à morte realizada por estas heroínas representaria uma morte gloriosa e heroica ou seria, em contraposição, aquela morte que não deveria ser seguida como modelo pelo imaginário da aristocracia romana de tal período.

Devemos levar em consideração que a obra Epistulae Heroidum foi construída por um poeta que fazia parte da aristocracia imperial romana e, ainda, que esteve inserido no ambiente da Aula Caesaris, além de ter participado do círculo literário de Messala Corvino. Ou seja, nossa investigação está pautada nas representações das relações amorosas romanas associadas à morte, uma vez que, de acordo com Roger Chartier: "as representaçōes do mundo social assim construídas, embora aspirem à universalidade de um diagnóstico fundado na razão, são sempre determinadas pelos interesses de grupo que as forjam" (CHARTIER, 2002, p. 17). Deste modo, as representações não são neutras, pois elas buscam atender aos interesses de cada imaginário social, bem como justificar e enfatizar as escolhas dos indivíduos que as constroem, além de almejarem estabelecer domínio sobre o real. Porém, mesmo que se intente estabelecer certo domínio sobre o mesmo, a visão construída dentro de Epistulae Heroidum não constitui a realidade, haja vista que nela se encontram ideais vislumbrados por um determinado grupo social e dirigidos a este mesmo grupo; neste caso, da aristocracia imperial romana. O que não quer dizer que tais aspiraçôes e ideais almejados foram de fato alcançados dentro dos próprios grupos para os quais foram dirigidos e, dentro dos grupos que ficaram à mercê destes intentos, os efeitos podem ter sido menos alcançados ainda. 
Dos documentos que nos chegaram, a fonte mais importante para obtermos informaçôes acerca da vida do poeta é sua própria obra Tristium, construída enquanto esteve no exílio em Tomos. Nascido em 23 de março de 43 a.C. (GREEN, 2011, p. 11), Ovídio, como a maioria dos poetas considerados romanos, não nasceu em Roma: "Minha pátria é Sulmona fertilíssima pelas suas águas frias, que dista de Roma noventa mil passos. Nasci nessa localidade" (Ovídio. Elexia $\mathrm{X}$ do Livro IV, Tristium, 5-9). No que se refere à sua linhagem, o poeta nos diz: "E se tem valor alguma coisa antiga, sou herdeiro da Ordem Equestre, ininterruptamente, de meus antepassados: não fui feito cavaleiro há pouco por um favor da fortuna" (Ovídio. Elegia X do Livro IV, Tristium, 14-18). Foi educado em Roma, para que pudesse receber formação jurídica e retórica, como forma de preparo para uma carreira política (VOLK, 2010, p. 23). Porém, o poeta não seguiu a vida no Senado, optando por dedicar-se à poesia: "Mas a mim já agradavam desde criança o culto das musas; e a musa atraía-me secretamente para seu culto" (Ovídio. Elegia X do Livro IV, Tristium, 37-40).

No ano 8 d.C., Ovídio foi degredado por Augusto nas circunstâncias em que: "[...] a cólera do Príncipe ofendido ordena que me dirija para Tomos situada à esquerda do mar Euxino" (Ovídio. Elegia X do Livro IV, Tristium, 167-70). Os reais motivos para tal desterro são desconhecidos, mas algumas hipóteses giram em torno da imoralidade atribuída à sua obra Ars Amatoria. Porém, importa ressaltarmos que a obra que a historiografia comumente aponta como a causa do exílio do poeta possui, entre sua possível data de circulação e o ano em que o poeta foi desterrado, doze anos de distanciamento.

No Império Romano, especialmente durante o Principado de Augusto, para que o Príncipe intentasse enviar alguém para o desterro não era necessário um crime, talvez nem mesmo algum pretexto formal e oficial. No caso de Ovídio, acreditamos que Augusto não esperaria por doze anos para que pudesse enviá-lo ao exílio. Nas palavras do poeta: "Sou castigado porque meus olhos desprevenidos surpreenderam um escândalo: e meu crime é ter olhos. Não poderei certamente defender-me de toda culpa, mas a imprudência faz parte de minha falta" (Ovídio. Elegia V do Livro III, Tris- 
1. De acordo com Katharina Volk (2010, p. 6), o trabalho de Ovídio pode ser dividido em três fases: Nos primeiros 25 anos de sua carreira, Ovídio elaborou uma série de livros pertencentes ao gênero elegíaco, os quais tratam, sobretudo, de temas relacionados ao amor. Nos seis anos decorrentes até a data de seu exílio, em 8 d.C., ele trabalhou com seus mais longos poemas, Metamorphoseon Libri e Fasti. A terceira fase compreende o período em que esteve exilado até sua morte. De suas obras produzidas neste período nos chegaram Tristium, Epistulae ex Ponto e Ibis. tium, 105-112). E, ainda, ao implorar o perdão do Príncipe, o poeta conclama: "Nem condenaste meus trabalhos por um decreto do Senado, nem meu exílio foi ordenado por um juiz especial. Tu próprio levado por palavras severas vingaste as injúrias que recebestes, como é digno de um Príncipe" (Ovídio. Elegia única do Livro II, Tristium, 316-324). Devemos levar em consideração que os argumentos de Ovídio acerca de seu exílio podem estar carregados de elementos retóricos que contribuam com suas intencionalidades, e ainda estamos lidando somente com a ótica do poeta sobre seu próprio desterro, o que dificulta a realização de afirmações que não sejam meras hipóteses acerca deste tema.

Ovídio faz alusão ao erro que cometeu não como um crime perante o Império, o que parece estar muito mais ligado a um erro pessoal, a uma quebra dos laços de amicitia do que ao conteúdo imoral de alguma obra sua. No que se refere às causas do exílio, nossa perspectiva caminha ao encontro da abordada por Fergus Millar, ao defender que nas obras escritas pelo poeta, mesmo que não em todas, fica evidente seu compromisso literário para com o novo regime, o que não quer dizer que seja, também, um compromisso pessoal, até porque não temos conhecimento acerca deste aspecto (MILLAR, 2002, p. 322). Em 17 ou 18 d.C. o poeta faleceu na cidade em que se encontrava exilado. De suas obras que nos chegaram, podemos citar Amores, Ars Amatoria, Epistulae Heroidum, De Medicamine Faciei Femineae, Remedia Amoris, Metamorphoseon Libri, Ibis, Fasti, Tristium e Epistulae ex Ponto, tendo sido as duas últimas escritas durante seu exílio.

A obra Epistulae Heroidum, mais conhecida como Heroides, possui a data ${ }^{1}$ de sua produção incerta. Mas acredita-se que tenha sido escrita, ao menos em partes, por volta do último trimestre do século I a.C. (VOLK, 2010, p. 8), pelo fato de Ovídio realizar referências acerca da elaboração desta dentro de sua primeira obra, Amores:

Já que é isso que me é consentido, que eu professe as artes meigas do Amor (pobre de mim, os meus próprios preceitos me atormentam!); ou uma carta para Penélope enviar a Ulisses, isso é o que hei de escrever, e as tuas lágrimas, ó Fílis, por teres sido abandonada, e cartas para lerem Páris e Macareu e outra para ler o mal-agradecido Jasão e o pai de Hipólito e Hipólito, 
e as palavras que a infeliz Dido, de espada em punho, há de proferir e as que há de proferir a poeta de Lesbos, a dedilhar a lira da Aônia (Ovídio. Amores, 19-26).

O documento Epistulae Heroidum é composto por vinte e uma epístolas construídas por Ovídio e representadas na voz de heroínas e heróis provenientes do relato mítico, sobretudo grego $^{2}$, e uma personagem proveniente da História, Safo. O primeiro grupo é composto por quinze epístolas que possuem como remetentes heroínas, as quais Ovídio constituiu como se tivessem escrito e endereçado missivas aos seus amados, os quais se encontravam ausentes, porém não obtiveram resposta. Nelas o poeta, através das heroínas, utilizou-se do manuseio das palavras e dos elementos de persuasão, na intenção de construir suas relaçôes, expressar o desespero provocado pelo amor desmedido e pelo abandono sofrido, bem como a esperança pelo retorno dos heróis. As epístolas construídas pelo poeta neste grupo são: Epístola I: Penélope a Ulisses; Epístola II: Fílis a Demofoonte; Epístola III: Briseis a Aquiles; Epístola IV: Fedra a Hipólito; Epístola V: Enone a Páris; Epístola VI: Hipsípile a Jasão; Epístola VII: Dido a Enéias; Epístola VIII: Hermíone a Orestes; Epístola IX: Dejanira a Hércules; Epístola X: Ariadne a Teseu; Epístola XI: Cânane a Macareu; Epístola XII: Medéia a Jasão; Epístola XIII: Laodâmia a Protesilau; Epístola XIV: Hipermnestra a Linceu; Epístola $\mathrm{XV}$ : Safo a Fáon. O segundo grupo é composto por epístolas emparelhadas, as quais Ovídio construiu como se heróis representassem os remetentes e as heroínas as destinatárias, as quais responderam às missivas. Dentro deste segundo grupo, temos: Epístola XVI: Páris a Helena; Epístola XVII: Helena a Páris; Epístola XVIII: Leandro a Hero; Epístola XIX: Hero a Leandro; Epístola XX: Acôncio a Cídipe; Epístola XXI: Cídipe a Acôncio. Para Stephen Harrison, estes três pares de epístolas duplas acrescentaram o elemento do debate retórico (HARRISON, 2002, p. 83).

No primeiro grupo, composto pelas epístolas simples, possui nos primeiros versos a saudação da heroína remetente ao herói destinatário, além de apresentar os motivos que as levaram a escrever tal missiva, bem como as queixas do abandono sofrido. Ao longo da narratio, há a exposição do desejo de serem amadas, bem como pelo retorno dos heróis, além
2. Apenas a epístola de Dido a Enéas foi fundamentada no relato mítico romano. Percebemos, através da própria constituição desta obra, a interpretatio graeca. Porém, ao afirmarmos que a obra é, em grande parte, constituída por mitos gregos, não significa afirmar que Roma é uma cópia da Grécia, até mesmo porque os mitos (e outros elementos sociais, políticos e culturais) não são apropriados, mas constantemente resignificados e reinterpretados de acordo com as necessidades $\mathrm{e}$ intencionalidades de cada contexto e autor. De acordo com Galinsky (1996, p. 332), tal influência foi mútua e se deve ao contato intensivo, comercial e cultural, entre Grécia e Roma desde o momento da fundação da segunda. 
das súplicas para que isto aconteça. Existem ainda os momentos de lucidez, nos quais as heroínas percebem os males do amor e questionam se o amor atribuído à pessoa amada é uma culpa ou um mérito. Narram, em seguida, as esperanças acerca do possível retorno do herói, bem como queixas de possíveis infidelidades. No final da epístola, há a narratio acerca dos males sofridos e ansiedades, tendo como ápice em muitas epístolas a alternativa do suicídio (PÉREZ VEGA, 1994, p. 33). No que se refere às epístolas duplas, a narratio possui muitas similitudes com as demais epístolas: as missivas construídas na voz de heróis como remetentes centra-se na descrição do amor, bem como na tentativa de uma argumentação convincente para que as heroínas acreditem na demora de seu retorno, bem como para que possam ceder ao amor e às súplicas dos mesmos. Nas epístolas que representam as respostas aos heróis, tem-se a introdução, na qual as heroínas saúdam os heróis e, ao longo da narratio as heroínas realizam súplicas para o breve retorno dos amados, além de também apresentarem rasgos de lucidez em que questionam se tal demora de fato se justifica pelos argumentos apresentados pelos heróis, ou se constituem-se apenas como pretextos. A alusão à morte também se faz presente neste grupo e constitui fortemente um aparato retórico.

Ao embasar-se amplamente na retórica, Ovídio utilizou-se de elementos como suasoria (exercício retórico de persuasão), especialmente nas 15 primeiras epístolas. Utilizou-se também da controuersia (debate retórico sobre um caso hipotético) nas 6 epístolas duplas (PÉREZ VEGA, 1994, p. 15). Outro elemento retórico amplamente utilizado foi a ethopeia, em que o poeta deveria imaginar a si próprio no papel de uma importante personagem histórica ou proveniente do mito e, a partir disto, construir um discurso apropriado a um determinado momento, recurso este que está presente em todas as epístolas (LOPES, 2010, p. 91).

Dentro das Heroides, Ovídio pouco diz, de maneira explícita, sobre o gênero da obra através de suas próprias personagens, a não ser na epístola XV, de Safo a Faón:

Teus olhos, lendo esta carta, escrita por mão devota, reconheceram logo minha letra, ou, se não tivesses lido o nome de Safo, que a traçou, saberias quem te enviou um bilhete tão 
breve? Talvez também te perguntes porque escolhi versos com tamanhos diferentes, quando estou mais acostumada aos ritmos da lira. Preciso chorar sobre meu amor; a elegia é um canto choroso; nenhum alaúde convém às minhas lágrimas (Ovídio. Epístola de Safo a Fáon, Epistulae Heroidum, 1-9).

Ovídio enfatiza, na voz de Safo, as características da Elegia ligadas às lamentações do amor. "É claro (apesar de que Safo não faz este ponto) que não é apenas seu modo melancólico que faz com que as Heroides seja propriamente elegíaca, mas também seu conteúdo amoroso" (VOLK, 2010, p. 41). $\mathrm{E}$, ainda, de acordo com Roy Gibson, o gênero elegíaco não representa a união trazida pelo amor, mas o contrário. Comumente a Elegia traz elementos relacionados ao amor desmedido, e também elementos de constante confronto, podendo a personagem expressar sua submissão ao amor e à pessoa amada (GIBSON, 2005, p. 160).

Além do gênero elegíaco, tal obra engloba ainda o denominado gênero epistolar. Sabe-se que a utilização do termo epístola, e não cartas, faz-se mais viável para caracterizar as missivas componentes desta obra por concordarmos com o autor José Carlos Martín (2007, p. 11), ao afirmar que a distinção entre carta e epístola já foi superada no mundo antigo. Tal autor cita A. Deissmann, o qual acredita que carta é o texto enviado de fato a um destinatário preciso, enquanto epístola seria o texto enviado de forma ficcional a um destinatário existente ou não. Catharine Edwards (2005, p. 270) salienta que para ser uma epístola deve, em primeiro lugar, haver um destinatário e um remetente. Consequentemente, o elemento que se faz de fundamental importância é a separação entre quem escreve e o destinatário. A epístola serve para superar uma distância e, ao mesmo tempo, para nos lembrar de que existe a distância entre quem escreve e o destinatário. Cabe ao escritor enfatizar a proximidade que a carta pode trazer, ou a distância a que ela se remete. No caso de Ovídio, o foco está na distância a que a missiva se remete. Além destas características, devemos levar em consideração que, no caso das Heroides, o apelo e o discurso contidos dentro das missivas eram, evidentemente, mais destinados ao público do que propriamente ao destinatário ficcional. ${ }^{3}$

\footnotetext{
3. Concordamos com Paul Veyne (1995, p. 118), ao argumentar que o gênero consolatório constituía um gênero destinado não somente ao remetente e ao destinatário, mas o público que o leria. Acreditamos que esta característica se faz fortemente presente dentro de Epistulae Heroidum.
} 
4. Tal nomenclatura designa uma mudança de regime político que não foi sentida desta forma pelos romanos. Os historiadores passaram a utilizar este termo a fim de ordenar a História Romana, bem como devido à modificação que perceberam dentro da política e da sociedade latina.
Tendo sido escrita em finais do século I a.C., a obra Epistulae Heroidum foi produzida no seio do Principado de Augusto. ${ }^{4}$ Sabe-se que em finais da República, Roma havia passado por inúmeras guerras civis, as quais acabaram por acarretar no enfraquecimento político da mesma e, principalmente, do mos maiorum. Os anos posteriores ao assassinato de Júlio César foram permeados por constantes e desgastantes guerras civis, bem como pelo embate entre Augusto e adversários fortes, a fim do primeiro conquistar sua supremacia política e militar. Tais conflitos ocasionaram o aumento do número de mortes de homens que iam lutar na guerra, consequentemente o número de casamentos entre pessoas pertencentes à aristocracia imperial romana tornou-se escasso, o que acarretou na redução do nascimento de crianças legítimas. A família, instituição que exercia um papel fundamental dentro da moral romana, encontrava-se fragmentada com estas guerras.

Com a vitória na batalha de Áccio, em 31 a.C., a detenção do poder sobre o Império centrou-se em Augusto, o qual esforçou-se em consolidar sua vitória e em promover medidas para um governo estável, se pondo como o mantenedor da tradição e dos costumes romanos e restaurador da República. Porém, devemos nos atentar ao detalhe de que o Princeps, mesmo tendo optado pela tentativa de encerrar as guerras civis, o que muitas vezes é denominado pela historiografia como Pax Romana, o mesmo não deixou de promover, mas, de acordo Joseph Farrel (2005, p. 44), pelo contrário, incentivar e investir em guerras contra os inimigos externos com a finalidade de anexação de territórios. Comumente, historiadores e poetas que escreveram durante o Principado de Augusto, ou até mesmo sobre o Princeps, mas em períodos posteriores, apontam que, uma vez instaurada a Pax Romana, o clima de paz e estabilidade foi retomado, assim como a recuperação das antigas leis provenientes da República. Nas palavras de Veléio Patérculo:

Se pôs fim às guerras civis depois de vinte anos, se deu fim às campanhas exteriores, retomou a paz; [...] se reestabeleceram as leis em seu antigo vigor. [...] Aquela inveterada e antiga constituição do estado foi recuperada. Os campos voltaram a cultivar-se, se devolveu sua solenidade ao culto religioso, os homens se encontravam de novo seguros [...] Os homens mais notáveis que recebiam triunfos e grandes honras custearam 
obras de magnificência para a cidade a instâncias a mando do príncipe (Veléio Patérculo. História Romana, 3-5).

A historiografia atual comumente reproduz este ideal do governo de Augusto presente nos escritos de historiadores e poetas do período. Acreditam que, uma vez instaurada a Pax Romana, o suposto clima de paz e estabilidade deu espaço e condiçōes favoráveis para que a arte fosse desenvolvida, sobretudo a poesia. No entanto, não deixando de lado a capacidade artística de cada poeta, a poesia nos parece muito mais um instrumento utilizado por Augusto - através dos círculos literários de Mecenas e Messala Corvino - para propagar tal ideal de paz e estabilidade e de um governo memorável, em um ambiente em que ainda havia conflitos entre distintos grupos dentro da própria aristocracia romana, do que fruto de uma harmonia da urbs.

Augusto preocupou-se em também repor na ordem determinados valores que acreditava ser essenciais aos romanos e em salvaguardar aspectos do passado que pudessem reforçar o sentimento religioso e, sobretudo, reforçar a moral romana (GRIMAL, 1997, p. 75). Logo no início de seu governo, além de enfatizar a imagem de restaurador da res publica e de mantenedor dos costumes e da paz, buscou realizar a sucessão imperial através de sua família. O Princeps investiu fortemente na sucessão dinástica a partir da gens Iulia, dentro de uma sociedade patriarcal como era Roma deste período, em que as mulheres não tinham direito de participar diretamente na política, mas que possuíam uma grande importância dentro da própria sucessão que Augusto tanto enfatizou. As mulheres eram as responsáveis pela legitimidade da linhagem dos prováveis sucessores, como aponta María José Hidalgo de La Vega, em seu livro Las Emperatrices Romanas: sueños de púrpura y poder oculto: "[...] Este modelo se constrói como uma organização patriarcal da vida familiar em que Augusto exerce sua autoridade sobre sua filha, netos e filhos, mas onde o papel da relação pai-filha ocupa um posto central, típico, por outra parte, das famílias aristocráticas romanas" (HIDALGO DE LA VEGA, 2012, p. 24).

A produção da obra ovidiana encontra-se dentro deste contexto, em que Augusto estabelece políticas de incentivos matrimoniais e de regulamentações do adultério, não só com 
5. "A corte não é simplesmente a casa do governante, mas a casa a operar como uma interface com a sociedade sobre a qual ele governa" (WALLACE-HADRILL, 2008, p. 289). Ou seja, as pessoas pertencentes à corte imperial e, sobretudo pertencentes aos círculos que Augusto patrocinava,

como o de Mecenas e Messala, deveriam operar como uma forma de ligação com a aristocracia com a qual Augusto governava. Deveria operar de acordo com os moldes do Imperador, e ainda de acordo com a moral romana, com valores atribuídos ao casamento e à família. a finalidade de buscar a sucessão dinástica através da gens Iulia, mas também com a finalidade de se estabelecer um controle sobre a própria aristocracia imperial romana, ao se elencar e retomar padrões de uma típica matrona da República, que deveria ser detentora de pudicitia, fidelitas, iustitia, pietas, clementia e moderatio. E, ao mesmo tempo, estabeleciam-se condutas apropriadas ao típico cidadão romano, o qual deveria ser detentor da honra, sensatez e sobriedade. A reforma moral empreendida por Augusto, que se iniciava dentro da própria domus Augusta, deveria ter, como função primordial, servir de exemplo para as pessoas pertencentes ao círculo de amizade do Princeps, bem como aos grupos pertencentes à aristocracia imperial romana.

A fim de alcançar tais objetivos, sobretudo através do círculo organizado por Mecenas, Otávio Augusto incentivou poetas que pudessem mesclar as tradições ainda vivas com o fim das guerras civis e o governo estável conquistado. Ovídio "[...] se liga, portanto, ao círculo literário de Messala Corvino, onde está Tibulo, mas também se tornou amigo dos poetas (sobretudo Propércio e Horácio) do outro círculo, mais conhecido em torno da figura de Mecenas" (ROSATI, 2011, p. 47).

O fato de Ovídio ter pertencido a um círculo literário patrocinado por Augusto é de fundamental importância para nossa análise, uma vez que, consequentemente, ele também fez parte do ambiente da corte imperial. ${ }^{5}$ De acordo com Andrew Wallace-Hadrill, como as demais pessoas que faziam parte deste ambiente, o poeta atuava como intermediário e beneficiário entre as normas ditadas por Augusto e a aristocracia (WALLACE-HADRILL, 2008, p. 297). E ainda, de acordo com Mario Citroni:

Sempre foi difícil evitar a idéia de que deve ter havido uma conexão entre o nível excepcional da produção poética desses anos e o extraordinário sucesso das políticas de Augusto. [...] É claro que houve a intenção de estimular a produção poética e orientá-la adequadamente a fim de criar e consolidar a imagem de Augusto como o fundador de um novo período de esplendor ainda maior para Roma após os desastres das guerras civis. Acima de tudo, uma parte considerável das poesias do período de Augusto pode ser rastreada até chegar aos temas 
morais, cívicos e religiosos que caracterizam a ideologia de seu regime (CITRONI, 2013, p. 8).

A morte, enquanto um fenômeno não apenas biológico, mas também cultural, foi e é compreendida e percebida com suas especificidades em diferentes recortes temporais, espaciais e culturais. Por perceberem que a vida é efêmera, cada cultura irá se amparar em determinados aparatos com a finalidade de atribuir sentido e significado, cada qual ao seu modo, a esta grande ruptura e contingência que o ser humano tem que enfrentar: a morte e, com ela, suas implicaçóes.

Dentro deste contexto de início do Império, Roma lidava de forma intensa - no sentido quantitativo - com a morte. Em um período em que guerras civis eram recém-findadas e as guerras externas pela anexação de territórios aconteciam em grande escala, muitas pessoas morreram, além das baixas condições de saneamento que ocasionaram a maior vulnerabilidade da vida das pessoas que ali viviam.

Sob estas circunstâncias, os rituais funerários assumiram fundamental importância para muitos grupos sociais da urbs romana de finais do século I a.C. e início do I d.C.. De acordo com a historiadora Darja Sterbenc Erker em seu artigo intitulado "Gender and roman funeral ritual", as práticas funerárias romanas aconteciam no intento de se mostrar que o indivíduo que faleceu deveria ser preparado para deixar o mundo dos vivos através de uma série de rituais. Rituais estes que, para a mesma autora, expressam a passagem de uma morte física para uma morte cultural (ERKER, 2011, p. 40). Tais ritos fúnebres possuíam grande importância para aqueles que permaneciam em vida, os enlutados, uma vez que a tentativa de preservação da memória do morto para a posteridade era destinada, sobretudo, à própria família e aos círculos de amizade da pessoa que outrora morrera. Para Erker, ao morrer algum membro da família, as demais pessoas passam a estar contaminadas e, para que a descontaminação ocorra, há a obrigação de se realizar os ritos fúnebres até o final (ERKER, 2011, p. 42), até mesmo porque, de acordo com Hugh Lindsay, os rituais de purificação pelos quais a família e a casa do morto passavam constituíam uma limpeza que era, ao mesmo tempo, moral e física (LINDSAY, 2000, p. 152). ${ }^{6}$
6. De acordo com Hugh
Lindsay, durante o retorno
do funeral, aqueles que
haviam participado
deveriam ser purificados
com fogo e água, o que é
denominado como suffitio.
Os rituais envolviam o
uso de um ramo de louro
para borrifar água sobre
os participantes, e após
isso passavam sob o fogo
(LINDSAY, 2000, p. 167). 
Ao mencionarmos a importância dos rituais fúnebres para esta sociedade, nos remetemos à própria morte do poeta Ovídio, ou melhor, à forma como supostamente o poeta veio a falecer. Nas palavras deste:

Se, finalmente, minha sorte completou os anos, que devia, e o fim da vida chegou para mim tão depressa, tanto quanto é possível, ó grandes deuses, poupai ao que vai morrer, para que ao menos seja sepultado na terra pátria! Ainda que a punição fosse adiada para a ocasiáo da morte, ou a morte precipitada antecipasse o desterro. [...] Morrerei, pois, tão longe em regiōes desconhecidas, e minha morte será mais horrível neste mesmo lugar? Meu corpo não definhará no leito costumado? Ninguém haverá que me chore depois de morto? Nem um curto momento sobreviverá a minha alma com as lágrimas de minha esposa caindo em minhas faces? Não farei recomendações? A mão amiga não fechará com o último grito meus olhos esvaecidos? Pois bem a terra estrangeira cobrirá sem funerais, sem a homenagem de um túmulo, este corpo não pranteado? (Ovídio. Elegia III do Livro III, Tristium, 68-99).

Fica em evidência o receio do poeta de falecer em "terra bárbara”, sem sequer dispor de ritos funerários e um túmulo. Receio da morte e, para além dela, do pós-morte. O poeta se queixa de que não terá as lágrimas de sua esposa, o que constituía um ritual de fundamental importância durante tal período. Com a morte de uma pessoa, os olhos do falecido deveriam ser fechados por um parente próximo, de preferência pertencente ao sexo feminino (LINDSAY, 2000, p. 162). De acordo com o autor David Noy (2011, p. 4), o receio de se morrer nestas condições descritas por Ovídio parece permear os cidadãos romanos pertencentes a este período pela possibilidade do ideal de morte, para os mesmos, estar centrado na morte ocorrida de maneira pacífica e, sobretudo, em um ambiente doméstico, em que o morto deveria estar rodeado por seus familiares. Ainda, para este mesmo autor, tal importância se dá pela necessidade de rememoração da morte e pelas açōes dos enlutados, ou seja, a função social da morte se dava tanto pela preservação da memória do morto quanto pela possibilidade de realização de seus últimos desejos, uma vez que estaria rodeado por pessoas próximas (NOY, 2011, p. 6). 
Tal importância delegada aos rituais fúnebres aparece também dentro da própria obra Epistulae Heroidum. Neste documento, há a intensa menção, por parte das heroínas, do cruel destino relegado a elas: a possibilidade de possuir um corpo sem sepultura. Na epístola de Fílis a Demofoonte podemos perceber tais traços quando o poeta, na voz da heroína, afirma:

Vem ao meu espírito a ideia de precipitar-me dali nas ondas que banham a base, e já que tua traição me empurra, realizarei meu desejo. Que as vagas levem meus despojos para as margens que habitas e que meu corpo sem sepultura se ofereça a teus olhos (Ovídio. Epístola de Fílis a Demofoonte, Epistulae Heroidum, 131-136).

E, ainda, na epístola construída na voz de Cânace como remetente e Macareu como destinatário - heroína da mitologia grega que se envolveu com seu irmão e juntos tiveram um filho - Ovídio constrói o relato nas circunstâncias em que o pai da heroína, sabendo do crime de incesto entre os irmãos, ordena que a criança seja abandonada junto aos animais e que a filha morra, enviando a ela uma espada. A heroína suplica ao amado Macareu que ao menos uma única urna guarde seus despojos e de seu filho:

E tu, tu que esperas em vão uma irmã infeliz, recolhe, suplico, os membros dispersos de teu filho; devolva-os a sua mãe; que eles repousem num túmulo comum, e que uma só urna, por menor que seja, guarde as cinzas de nós dois. [Vive guardando minha lembrança; espalha lágrimas sobre minha ferida; amante, não temas o corpo de tua amante. Realiza, imploro, as vontades de uma irmã tão infortunada: executarei eu mesma as de meu pai] (Ovídio. Epístola de Cânace a Macareu, Epistulae Heroidum, 124-131).

Sabemos que na cultura clássica, neste caso especificamente no imaginário da sociedade romana do século I a.C./I d.C., um corpo que fosse mal enterrado ou até mesmo mal cremado seria, consequentemente, relegado ao desprezo e à desonra (HOPE, 2009, p 179). Para os grupos aristocráticos desta sociedade, o pós-morte, que englobava uma série de ri- 
tos, incluindo o sepultamento do corpo, possuía fundamental importância. E, para além da importância delegada a tais rituais, o corpo ultrajado, o cadáver que não dispusesse de um sepultamento, estaria seriamente condenado ao esquecimento, poderia ser considerado como infame por não ter recebido tratamentos adequados e nem sequer rituais realizados no âmbito doméstico. Comumente temos como corpos insepultos aqueles que foram vencidos nas guerras, à mercê das feras $\mathrm{e}$ das aves de rapina. Acreditamos que, talvez, o receio por parte das heroínas de sofrerem a infâmia de ter um corpo insepulto se deva ao fato delas terem sido vencidas, não pela guerra, mas pelo amor desmedido.

Além do receio de se ter um corpo insepulto, percebemos também a importância ressaltada pelas mesmas de se morrer sob o olhar de seus familiares e em ambiente doméstico, importância esta enfatizada ora pela referência às pessoas que presenciarão a morte, ora através do receio de se morrer à mercê deste olhar familiar. Podemos perceber tais aspectos, por exemplo, por intermédio, da epístola de Dido a Enéias, quando a heroína afirma que sua irmã Ana será a pessoa que cuidará das oferendas destinas ao seu corpo:

Caso contrário, estou decidida a tirar-me a vida. Não podes ser cruel comigo muito tempo. Oxalá pudesse ver minha triste imagem enquanto te escrevo; estou escrevendo em presença de uma espada troiana que tenho no colo; as lágrimas me caem das bochechas sobre a espada desenhada, que em breve estará manchada de sangue em vez de lágrimas. [...] Ana, irmã, Ana, minha irmã minha, cúmplice de minha falha, que irá logo oferecer às minhas cinzas as últimas oferendas (Ovídio. Epístola de Dido a Enéias, Epistulae Heroidum, 184-199).

Já Ariadne, construída enquanto remetente de uma epístola a Teseu, teme sua morte longe dos olhos e das lágrimas de sua mãe:

Prestes a morrer, não verei as lágrimas de uma mãe e nem haverá quem me feche os olhos. Minha infortunada alma levantará voo sob um céu estrangeiro e não haverá uma mão amiga para ungir meu corpo reclinado. Os pássaros marinhos posarão sobre meus ossos insepultos; É esta a sepultura que 
meus favores merecem (Ovídio. Epístola de Ariadne a Teseu, Epistulae Heroidum, 119-125).

O ideal construído para o leito de morte consiste no seu revestimento pela domesticidade. A pessoa considerada digna deveria ter, durante seus momentos finais, seus familiares, amigos íntimos e médicos por perto. Tal morte deveria ser encarada com força e bravura sem demonstração qualquer de dor ou sofrimento (HOPE, 2009, p. 55). Ainda de acordo com Valerie Hope, para que a pessoa pudesse ter uma boa morte, ela deveria, além de demonstrar coragem e dignidade, proferir suas últimas palavras, ser lamentada por seus entes queridos, ter o corpo bem tratado e até mesmo ser uma pessoa honrada por inimigos (HOPE, 2007, p. 43).

Passemos à discussão acerca das reafirmações de modelos $^{7}$ a serem seguidos e outros a serem negados, haja vista que, para Ovídio, as heroínas por ele construídas parecem colocar em questão modelos e contra-modelos até mesmo nos momentos em que fazem alusão à morte. Talvez isto se faça possível pelo simples fato das heroínas ovidianas terem demonstrado, ao longo da narrativa nas epístolas, ausência de controle, honra e sobriedade em relação ao amor e aos atos decorrentes das desmedidas do mesmo, embora elas apresentem momentos de lucidez ao enfatizarem os males provocados por tais desmesuras. Tal ambiguidade das ações se faz presente até mesmo durante as menções à morte, enfatizando, talvez, que o descontrole tido em vida não poderia ser diferente no momento da morte, deixando espaço, ao mesmo tempo, para se reafirmar o ideal de morte esperado. Morte esta que poderia fornecer às heroínas a honra e o pudor que elas não possuíram ou não conseguiram manter em vida.

Muitos dos poetas pertencentes ao período augustano, ao enfatizarem em seus discursos as paixões, o faziam como uma forma de confirmar os juízos e valores vigentes nesta sociedade (KASTER, 2006, p. 324). Podemos perceber tal confirmação da moral romana presente em Epistulae Heroidum, quando Ovídio enfatiza, na voz dos heróis e heroínas, uma situação de ambivalência sobre o amor e o amado ao demonstrar a paixão, através da entrega total e das declarações de amor à pessoa amada, ao mesmo passo em que realiza julgamentos e avaliações sobre o amor desmedido através dos
7. Uma vez atribuindo modelos de comportamento esperados para os seres humanos pertencentes ao sexo feminino, atribuem-se, ao mesmo tempo, modelos de conduta esperados de um típico cidadão romano deste período. Mesmo que tal reafirmação recaia de forma mais intensa sobre as mulheres, uma vez que eram elas as responsáveis por atribuírem pureza à linhagem, podemos encontrar também tais exigências dirigidas aos homens. Na epístola de Briseis a Aquiles, na voz da heroína, o poeta coloca: "Não basta não teres tentado recuperarme: tu te opóes a que me devolvam, Aquiles. Vai, apresenta-te agora como amante apaixonado" (Ovídio. Epístola de Briseis a Aquiles. Epistulae Heroidum, 30-32). Ao questionar se Aquiles é capaz de tornar público e demonstrar seu amor por ela, nos remete ao ideal esperado do cidadão romano: detentor da honra, sensatez e sobriedade, o qual não deveria se deixar acometer pelos males do amor e, muito menos, tornar isto algo público. 
lamentos, como nos indica o fragmento retirado da epístola de Fílis a Demofonte:

Tenho ainda nos olhos o espetáculo de tua partida; vejo tua frota, pronta para navegar, estacionando em meus portos. Ousaste abraçar-me e, inclinado sobre o pescoço de tua amante, imprimir sobre meus lábios ternos e longos beijos, confundir tuas lágrimas com as minhas, queixar-te do favor dos ventos que enfunavam tuas velas e dizer-me, afastando-te, estas últimas palavras: 'Fílis, espera teu Demofoonte'. Esperaria por ti, que partiste para nunca mais ver-me? Esperaria pelas velas que evitam nossos mares? Todavia espero: volta para tua amante: já demoraste tanto! Que tua promessa tenha sido falsa somente quanto ao tempo (Ovídio. Epístola de Fílis a Demofoonte, Epistulae Heroidum, 90-106).

Ao mesmo tempo em que a heroína realiza súplicas de amor e pedidos para que o herói retorne, podemos perceber os momentos de lucidez e sensatez, nos quais ela percebe os males ocasionados por seu amor desmedido e questiona se deveria mesmo esperar pelo retorno do herói e, mesmo questionando, em seguida mantém o posicionamento de que continuará na espera pelo retorno. A esperança é renovada e há a utilização da retórica com a finalidade de convencer, pelas palavras, o amado a retornar aos seus braços.

Ao analisarmos o modo como a fonte Heroides foi construída por Ovídio, percebemos que o poeta elencou o relacionamento amoroso focando somente em relações entre homens e mulheres. Até mesmo Safo, poetisa grega conhecida por cantar suas poesias a outras mulheres, foi construída pelo poeta como a remetente de uma epístola a Fáon, um herói. Além disto, em sua primeira epístola, na qual temos Penélope como remetente e Ulisses como o destinatário, a heroína ressalta:

Nós somos três seres indefesos: tua esposa, uma frágil mulher, Laertes, um ancião, e Telêmaco, uma criança. [...] Que os deuses concedam, e eu peço que, acontecendo em sua ordem nossas mortes, feche meus olhos e feche também os teus! [...] Mas Laertes, como homem que já não está para empunhar armas, não é capaz de segurar o governo, rodeado de inimigos; a Telêmaco chegará, se conservar a vida, a hora de ser homem, 
mas por agora necessitaria da ajuda de seu pai para conservá-la. Tampouco eu tenho forças para expulsar do palácio os inimigos; tens que vir, nosso porto e nosso altar de salvação! Aqui tens teu filho, e queiram os deuses que o conserve, que em seus ternos anos deveria estar aprendendo tudo o que seu pai poderia ensiná-lo. Pensa também em Laertes: ele atrasou sua última hora apenas para que você feche os seus olhos. E quanto a mim, que era jovem quando me deixastes, por mais breve que venhas parecer-te-ei velha (Ovídio. Epístola de Penélope a Ulisses, Epistulae Heroidum, 98-117).

De acordo com Eva Cantarella, “[...] a organização familiar romana se apresenta como uma organização fortemente patriarcal [...]" (CANTARELLA, 1996, p. 193). A familia romana poderia ser representada por um grupo de pessoas sujeitas natura aut iure ao poder do pater familias (CANTARELLA, 1996, p. 195). Através do fragmento das Heroides exposto acima, percebemos que Ovídio coloca na voz de Penélope a necessidade do retorno de Ulisses, uma vez que a domus, bem como sua família (constituída por Penélope, o filho do casal, Telêmaco, e Laerte, pai de Ulisses) necessita de seus cuidados. Ovídio parece enfatizar nas epístolas a importância e a necessidade de se ter o herói por perto. Tal aspecto parece encontrar-se em harmonia com as principais características da tradicional família romana, falocêntrica, tão cara a esta moral.

Ao que nos parece, para os romanos dos séculos I a.C. e I d.C., o ideal de amor deveria tender ao equilíbrio, assim como todos os elementos da sociedade deveriam tender à harmonia do Universo. Deveria estar ligado à razão, àquele que garante a perpetuação da família, bem como ao culto aos ancestrais (GRIMAL, 1991, p. 2). Já sua desmedida, seu excesso estaria ligado à paixão, ao desejo, ao irracional, àquilo que ia contra a natureza e o equilíbrio das coisas. "A paixão não é uma passividade, mas um movimento, um movimento irracional da alma contrário à natureza, ou uma tendência sem medida" (BRUN, 1970, p. 80). E ainda, o que estaria ligado à paixão não constituía domínio da razão. Seria uma forma de submissão imposta, não uma ação premeditada (ANDRÉ, 2006, p. 234).

Para este homem antigo, o poder do amor irracional era tamanho que parecia transcender o pudor e a sensatez, ven- 
cendo a honra e a sobriedade. E tal poder parecia estar ligado à fúria e à incontestável figura do deus, uma vez que este é colocado, em muitos poemas, com a inicial em maiúsculo. De acordo com o autor José Ribeiro Ferreira, o Amor, na poesia da época arcaica poderia ser representado como poderoso, astuto e cruel, mas também como brincalhão, belo, jovem e desastrado. Tais características mantém-se, com pequenas alterações, durante a época clássica e, ainda de acordo com o mesmo autor, a concepção romana não difere substancialmente da grega nesta última fase (FERREIRA, 2004, p. 13). O que se mantém de comum é que o amor "surge de súbito e faz tremer as vítimas; é doce e queima o coração, ou, segundo Safo, é doce e amargo gluykýprikon" (FERREIRA, 2004, p. 14). Podemos perceber aspectos em sintonia com tais características no fragmento abaixo retirado da epístola de Fedra a Hipólito:

Três vezes tentei conversar contigo, três vezes minha língua calou impotente, três vezes o som veio morrer em meus lábios. O pudor deve, dentro do possível, misturar-se ao amor. Aquilo que não ousei dizer, o Amor me ordenou escrever, e às ordens que o Amor dá é perigoso desobedecer, Ele reina, impõe seus direitos aos deuses soberanos, Foi ele quem, vendo-me hesitar no início, disse: "Escreve; esse homem de ferro te estenderá suas mãos vencedoras". Que ele me proteja, e, como abrasa minhas veias com um fogo devorador, torne também teu coração aberto aos meus pedidos. (Ovídio. Epístola de Fedra a Hipólito, Epistulae Heroidum, 7-16).

Ovídio parece representar o amor desmedido ligado ao desejo e à paixão em contraposição ao amor ligado ao racional, àquele responsável por perpetuar a família, como podemos perceber através do seguinte fragmento, retirado da Epístola de Enone a Páris, em que o poeta explicita a desmedida das ações propiciadas pela paixão, deixando implícito, talvez, que o amor visado pela moral romana deveria ser o contrário da paixão:

Dali, avistei primeiro as velas de tuas embarcaçôes e quis, através das ondas, lançar-me ao teu encontro. Enquanto eu ainda oscilava, vi os ornamentos de púrpura brilhar no alto de tua proa. Estremeci; este ornamento não era o seu. Teu navio se 
aproximou, e, levado por um vento rápido abordou na praia. Vi então, com o coração batendo forte, um rosto de mulher. Não era suficiente? Por que, ainda, insensata, continuar ali? Tua indigna amante estreitava-se contra o teu peito. Então, feri e golpeei meu peito, dilacerei, com a ponta das unhas, minhas faces banhadas de lágrimas, enchi com meus gritos lastimosos o monte sagrado de Ida. Depois fui esconder minhas lágrimas nos antros que me são caros (Ovídio. Epístola de Enone a Páris, Epistulae Heroidum, 65-75).

À primeira vista, a menção ao suicídio aparece como um fator retórico ${ }^{8}$ : a tentativa de persuasão, através da vingança pelo abandono do herói e do amor deste, com a finalidade de se convencer o herói a retornar e amar novamente a heroína:

Juro por minha estirpe infortunada, pelo autor dessa estirpe, que faz mover os mares, a terra e o império celeste, pelos ossos de teu pai, meu tio, que, vingados por tua coragem, te devem a tumba onde repousam; ou morrerei jovem e serei colhida na flor da minha idade, ou, descendente de Tântalo, serei a esposa do descendente de Tânalo (Ovídio. Epístola de Hermíone a Orestes, Epistulae Heroidum, 118-123).

Por conseguinte, além do fator retórico, muitas das heroínas ovidianas se remetem ao desejo da mors voluntaria ${ }^{9}$ por não mais suportarem a ausência da pessoa amada, e por não mais aguentarem as dores ocasionadas pelo excesso e desmedida do amor, da paixão. Muitas delas realizam menção ao suicídio como última e única saída em meio ao tormento, por não mais suportarem o sofrimento e a dor. Devemos concordar com a autora Nicole Loreaux, ao pontuar que dentro das tragédias gregas, é pelos homens que as mulheres morrem, e pelos homens elas se matam com maior frequência, é como se a morte de um homem clamasse, consequentemente, pela morte de uma (sua mulher) para contrabalançar (LOREAUX, 1988, p. 51), o que não difere muito dos casos das próprias heroínas construídas por Ovídio, como podemos perceber no seguinte fragmento retirado da epístola de Dejanira a Hércules:
8. "Para se falar de retórica, é preciso uma situação em que haja pelo menos dois interlocutores, uma situação dialógica. E para que haja um discurso persuasivo ou argumentativo é preciso que haja também uma situação em que os interlocutores se reconheçam como passíveis de serem convencidos de alguma coisa. Pode-se ter uma situação social, ou mesmo uma relação individual, onde não se reconheça em alguém o estatuto ou capacidade de ser persuadido" (ROSSI, 2009, p. 191).

9. A palavra suicídio não é proveniente do vocabulário latino do período de Augusto. De acordo com a autora Joana Guimarães, a expressão latina mais utilizada para se remeter ao suicídio é mortem sibi consciere. E a expressão que exprime a vontade de concretizar tal ato é a mors voluntaria (GUIMARÁES, 2010, p. 12). 
Escrevia ainda quando um clamor me avisou que meu esposo pereceu sob a túnica envenenada que ganhou de mim. Infeliz! Que fiz eu? Até onde a fúria levou tua amante? Ímpia Dejanira, por que hesitas em morrer? (Teu esposo será dilacerado no meio do Etna, e tu, a causa de tal crime, sobreviverás a ele? $\mathrm{O}$ que me resta fazer para que me acreditem ser a esposa de Hércules? Sim, a morte será a recompensa de nossa união. Tu também, Meleagro, em mim reconhecerás uma irmã). Ímpia Dejanira, por que hesitas em morrer?] Ó família maldita! [...] Ímpia Dejanira, por que hesitas em morrer? Peço apenas uma coisa, em nome dos laços sagrados que nos uniram, que é nunca ser acusada de atentar a teus dias. Quando uma de tuas flechas atingiu o coração ávido de Nesso, ele gritou: "Esse sangue tem a virtude de reanimar o amor". Enviei-te o pano embebido com o veneno de Nesso. Ímpia Dejanira, por que hesitas em morrer? Adeus, meu velho pai, Gorge minha irmã; adeus minha pátria, e tu, meu irmão, que foste afastado da tua, e tu, luz deste dia, o último que meus olhos verão; e tu, meu esposo, possas viver! E tu, Hilo, meu filho, adeus (Ovídio. Epístola de Dejanira a Hércules, Epistulae Heroidum, 143-168).

O desejo de morrer presente na voz de tal heroína parece estar ligado ao que ela considera como seu erro: ter enviado a Hércules uma túnica envenenada, que seria a responsável pela morte do herói. O erro e todas as suas consequências se mostram em decorrência de um fator principal: novamente temos a recorrência das desmesuras do amor por parte das heroínas que realizam alusão ao suicídio e por parte também daquelas que não fazem tal alusão. No caso de Dejanira, a desmedida do seu amor ocasionou ciúmes e fúria, levando a heroína a agir pela vingança na intenção de provocar a morte do herói. A morte e a menção ao desejo de morrer nos aparecem aqui como fatores capazes de proporcionar a proximidade entre os dois amantes. Se não puderam estar juntos em vida, que tal união seja concretizada na morte. E, ao mesmo tempo, quando Dejanira conclama sua vontade de morrer, a morte aparece como aquela capaz de oferecer aquilo que ela não teve em vida: a honra que ela havia perdido ao cometer os erros decorrentes do desequilíbrio do amor sentido por Hércules. 
De acordo com Valerie Hope (2009, p. 59), o suicídio poderia assumir, nesta sociedade, um caráter dúbio. Ao mesmo tempo em que poderia significar uma boa morte, poderia também estar ligado a uma morte vergonhosa. $\mathrm{O}$ suicídio poderia ser encarado como digno caso fosse fruto de uma reflexão consciente e sábia; caso contrário, poderia ferir a honra e o ideal de morte. Deveria ser encarado de olhos abertos e sem medo, enquanto o suicídio desonroso seria fruto do desespero (HOPE, 2009, p. 58).

No caso das heroínas ovidianas, a alusão à morte realizada pelas mesmas ora está ligada à possível morte do amado herói, ora está ligada ao abandono sofrido e à dor extrema pelo não retorno e pela não retribuição do amor sentido; a morte passa a ser desejada pelas consequências do amor passional, do excesso e desmedida do mesmo. A dor é extrema e, por isto, a morte passa a ser tida como melhor opção, como podemos perceber na epístola de Ariadne a Teseu quando, na voz da heroína, Ovídio afirma:

Não me imolaste também, cruel, com a mesma clava que abateu meu irmão? Essa morte te isentou do juramento que me fizeste. Agora revejo não apenas os males que devo suportar, mas todos os que pode sofrer uma mulher abandonada. A morte se revela ao meu espírito sob mil aspectos diferentes. Sofremos menos recebendo-a do que esperando-a (Ovídio. Epístola de Ariadne a Teseu, Epistulae Heroidum, 79-82).

Como pontuou Valerie Hope, na morte algumas pessoas poderiam tornar-se aquilo que elas não haviam sido em vida (HOPE, 2007, p. 2). O desejo de morrer e a alusão ao suicídio que muitas heroínas realizam podem estar ligados à própria perda da honra e das virtudes que uma matrona romana deveria ter:

Receba, descendente de Dárdano, o canto de Elisa agonizante; o que lês são as minhas últimas palavras. Tal como, debruçado sobre os úmidos juncos, o cisne de branca plumagem canta à beira do Meandro, quando o destino o chama. Não é na esperança de dobrar-te com minha prece que te envio essas palavras; sou levada por um deus que me domi- 
na. Mas após ter perdido para um ingrato os frutos de meus favores, minha honra, um corpo casto e uma alma pudica, é pouco perder palavras (Ovídio. Epístola de Dido a Enéias, Epistulae Heroidum, 1-9).

Quando Dido menciona estar escrevendo suas últimas palavras, a morte nos parece estar associada à perda do que ela mesma menciona: a perda da honra, do corpo casto e da alma pudica. Isto prece estar em plena sintonia com o que, ainda de acordo com Valerie Hope, a tradição literária deste período, especialmente com Propércio, diz sobre a morte ocorrida em decorrência do descontrole do amor: tal morte constituía algo vergonhoso, mas, ao mesmo tempo, o que é vergonhoso merece morrer (HOPE, 2007, p. 37).

Por fim, mesmo que o suicídio das heroínas ovidianas não tenha sido levado a cabo, evidentemente por se tratar de epístolas e a menção à morte não ultrapassar o campo das palavras, tal recorrência à morte pode ter sido um recurso utilizado por Ovídio com dupla finalidade. Dupla finalidade esta que percorre toda sua obra Epistulae Heroidum: estabelecer modelos de conduta e de contra-conduta, modelos a serem seguidos e outros a serem negados, pois o cidadão não poderia fugir destes modelos ideais até mesmo no momento da morte. Primeiramente, a menção à morte aparece como uma atitude vergonhosa e desprovida de honra, já que se recorre a ela devido à ausência de controle das ações e sentimentos ocasionados pelos excessos do amor, bem como com a finalidade de persuasão e convencimento do retorno da pessoa amada, mas também podemos refletir tal menção como um ato até mesmo heroico e provido de glória e honra se pensarmos através do aspecto de que se recorre à morte como uma tentativa, alternativa e um ato último e imediato de se atingir a honra - honra esta que outrora se perdera no ato da entrega de forma desmedida aos encantos do amor findando de uma vez por todas com aquilo que deu início às próprias desmesuras das heroínas: a morte vencendo o amor irracional, a morte que finda as dores e os sofrimentos, a morte que finda os excessos e desmedidas das ações e emoções, a morte que finda, principalmente, as condutas construídas como aquelas que não estariam em sintonia com os ideais do mos maiorum. 


\section{A) Documentos textuais}

OVÍDIO. Cartas de amor: As Heróides. Trad. Dunia Marinho Silva. São Paulo: Landy, 2007.

OVIDIO. Cartas de las heroinas e Ibis. Trad. Ana Pérez Veja. Madrid: Gredos, 1994.

OVÍDIO. Amores \& Arte de amar. Trad. Carlos Ascenso André. São Paulo: Companhia das Letras, 2011.

OVÍDIO. Tristium. Trad. Augusto Velloso. Rio de Janeiro: Organização Simões, 1952.

VELEYO PATÉRCULO. Historia Romana. Trad. Maria Asunción Sánchez Manzano. Madrid: Gredos, 2001.

\section{B) Obras gerais:}

ANDRÉ, Carlos Ascenso. Caminhos do amor em Roma: sexo, amor e paixão na poesia latina do séc. I a.C. Lisboa: Cotovia, 2006.

BRUN, Jean. A Moral. In: O Estoicismo. Lisboa: Ediçōes 70, 1972.

CANTARELLA, Eva. La Calamidad Ambigua: condición e imagen de la mujer en la antigüedad griega y romana. Madrid: Clássicas, 1996.

CHARTIER, Roger. História Cultural: entre práticas e representaçôes. Lisboa: Difel, 2002.

CITRONI, Mario. Poetry in Augustan Rome. In: KNOX, Peter E. (ed.). A Companion to Ovid. Oxford: Wiley-Blackwell, 2013. p. 8-25.

EDWARDS, Catharine. Epistolography. In: HARRISON, Stephen (ed.). A Companion to Latin Literature. London: Blackwell, 2005. p. 270-284.

ERKER, Darja Sterbenc. Gender and roman funeral ritual. In: HOPE, Valerie M.; Huskinson, Janet (orgs.). Memory and Mourning: Studies on Roman Death. Oxford: Oxbow Books, 2011. p. 40-60. 
FARRELL, Joseph. The Augustan Period: 40 bc-ad 14. In: HARRISON, Stephen (ed.). A Companion to Latin Literature. London: Blackwell, 2005. p. 44-54.

FERREIRA, José Ribeiro. Amor e Morte na Cultura Clássica. Coimbra: Ariadne, 2004.

GALINSKY, Karl. Augustan Culture: an interpretive introduction. New Jersey: Princeton University Press, 1996.

GIBSON, Roy. Love Elegy. In: HARRISON, Stephen (ed.). A Companion to Latin Literature. London: Blackwell, 2005. p. 159-173.

GUIMARÃES, Joana. Suicídio mitico: uma luz sobre a antiguidade clássica. Coimbra: FCT, 2010.

GREEN, Peter. Prefácio. In: ANDRÉ, Carlos Ascenso. Amores \& Arte de amar/Ovídio. São Paulo: Companhia das Letras, 2011. p. 11-76.

GRIMAL, Pierre. O Amor em Roma. São Paulo: Martins Fontes, 1991.

1997. O Século de Augusto. Lisboa: Edições 70,

HARRISON, Stephen. Ovid and genre: evolutions of an elegist. In: HARDIE, Philip (ed.). The Cambridge companion to Ovid. Cambridge: University Press, 2002. p. 79-94.

HIDALGO DE LA VEGA, María José. Las Emperatrices Romanas: sueños de púrpura y poder oculto. Salamanca: Ediciones Universidad de Salamanca, 2012.

HOPE, Valerie M. Roman Death: the Dyind and the Dead in Ancient Rome. New York: Continuum, 2009.

ge, 2007. Death in Ancient Rome. London: Routled-

KASTER, Robert. The passions. In: HARRISON, Stephen (ed.). A Companion to Latin Literature. London: Blackwell, 2005. p. 319-330.

KONSTAN, David. A Amizade no Mundo Clássico. São Paulo: Odysseus, 2005.

LINDSAY, Hugh. Death-Pollution and Funerals in the City of Rome. In: HOPE, Valerie M.; MARSHALL, Eireann (orgs.). Death and Disease in the Ancient City. London: Routledge, 2000. p. 152-173. 
LOPES, Cecilia Gonçalves. Confluência genérica na Elegia Erótica de Ovídio ou a Elegia Erótica em elevação. Dissertação de mestrado defendida junto ao programa da Faculdade de Filosofia, Letras e Ciências Humanas da Universidade de São Paulo em 2010.

LORAUX, Nicole. Maneiras Trágicas de Matar uma Mulher. Rio de Janeiro: Jorge Zahar, 1998.

MARTÍN, José Carlos. Introdução do Epistolario (Libros I-X). In: Panegírico del emperador Trajano. Gayo Plinio Segundo (Plinio el joven). Madrid: Cátedra, 2007. p. 9-31.

MILLAR, Fergus. Ovid and the Domus Augusta: Rome Seen from Tomoi. In: (org.) Rome, the Greek World and the East. North Carolina: The University of North Carolina Press, 2002. p. 321-349.

NOY, David. Goodbye Livias: dying in the roman home. In: HOPE, Valerie M.; HUSKINSON, Janet (orgs.). Memory and Mourning: Studies on Roman Death. Oxford: Oxbow Books, 2011. p. 01-20.

PÉREZ VEGA, Ana. Introducciones. In: OVÍDIO. Cartas de las heroinas; Ibis/Ovídio. Madrid: Gredos, 1994. p. 9-18.

ROSATI, Gianpiero. Premessa al testo. In: NASONE, Publio Ovidio. Lettere di Eroine. Milano: BUR Classici greci e latini, 2011. p. 47-51.

ROSSI, Andréa Lúcia Dorini de Oliveira Carvalho. Política e Identidade nos Discursos de Dion Crisóstomo. In: FUNARI, Pedro Paulo A.; SILVA, Maria Aparecida de Oliveira (orgs.). Política e Identidades no Mundo Antigo. São Paulo: Annablume; Fapesp, 2009. p.190-217.

VEYNE, Paul. Séneca y el Estoicismo. México: Fondo de Cultura Econômica, 1995.

VOLK, Katharina. Ovid. London: Blackwell, 2010.

WALLACE-HADRILL, Andrew. The imperial court. In: BOWMAN, Alan K.; CHAMPLIN, Edward; LINTOTT, Andrew (eds.). The Cambridge Ancienty History. Cambridge: University Press, 2008. p. 283-308.

Recebido em março de 2014. Aprovado em julho de 2014. 
